\title{
Multiple Myeloma With Multilobated Plasma Cells: An Unusual and Challenging Morphological Variant
}

International Journal of Surgical Pathology

(C) The Author(s) 2017

Reprints and permissions:

sagepub.com/journalsPermissions.nav DOI: |0.||77//0668969|775047|

journals.sagepub.com/home/ijs

@SAGE

\section{Magda Zanelli, MD', Maria Cecilia Mengoli, MD'(D, Daniela Fanni, MD², Elisabetta Froio, MD', Loredana De Marco, MD', and Stefano Ascani, MD³}

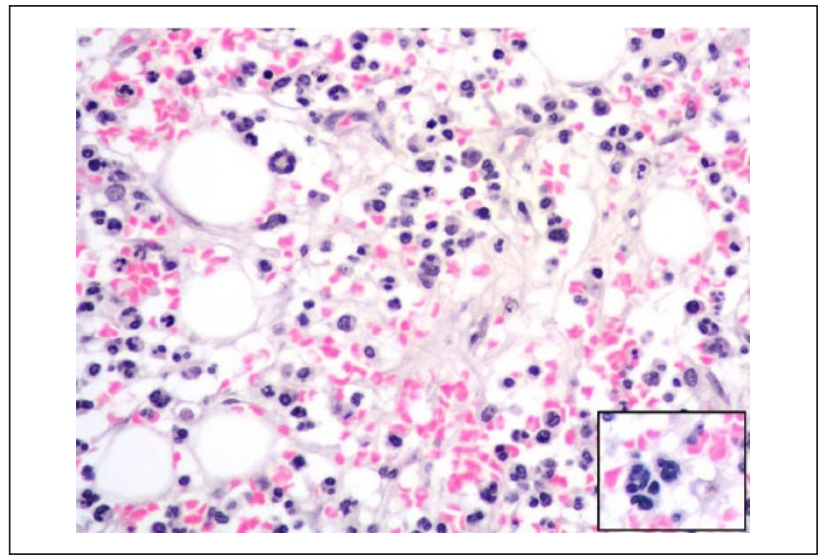

Figure I. Atypical, large, multilobated and multinucleated plasma cells infiltrating the bone marrow.

A 70-year-old man presented with fatigue and severe back pain. He had a diagnosis of serum monoclonal gammopathy $(\mathrm{IgG} / \mathrm{kappa})$ that remained stable and asymptomatic for 7 years. On admission, the laboratory findings showed anemia with low hemoglobin level $(9.5 \mathrm{~g} / \mathrm{dL})$, thrombocytopenia $(31000 / \mathrm{mmc})$, increased creatinine level $(4 \mathrm{mg} /$ dL) with creatinine clearance $13 \mathrm{~mL} / \mathrm{min}$, hypercalcemia $(14.3 \mathrm{mg} / \mathrm{dL})$, and a serum B2 microglobulin of $1.4 \mathrm{mg} / \mathrm{dL}$ (normal value $0.10-0.25$ ). Serum electrophoresis revealed a peak in the $\gamma$-globulin fraction, and immunofixation detected monoclonal $\mathrm{IgG} / \mathrm{kappa}$ in serum $(10.6 \mathrm{~g} / \mathrm{L})$ and kappa light chain in urine $(3.28 \mathrm{mg} / 24 \mathrm{~h})$. Bence Jones protein was present. Whole body radiographic scan and magnetic resonance imaging identified multiple lytic bone lesions in the cervical and thoracic spine and in the hip. Bone marrow biopsy showed a diffuse and massive infiltration by atypical, large multilobated and multinucleated cells with abundant cytoplasm (Figure 1), involving about $60 \%$ of bone marrow volume. The multilobated cells stained positive for CD138 (Figure 2A), MUM1/IRF4 (Figure 2B), and kappa chain (Figure 2C) and negative for CD20. A diagnosis of multiple myeloma with multilobated nuclei, stage III according Bartl, was made. Based on the cytogenetic abnormalities identified such as $\mathrm{t}(4 ; 14)$, deletion of TP53/17p11, and gain (1q21), the myeloma was

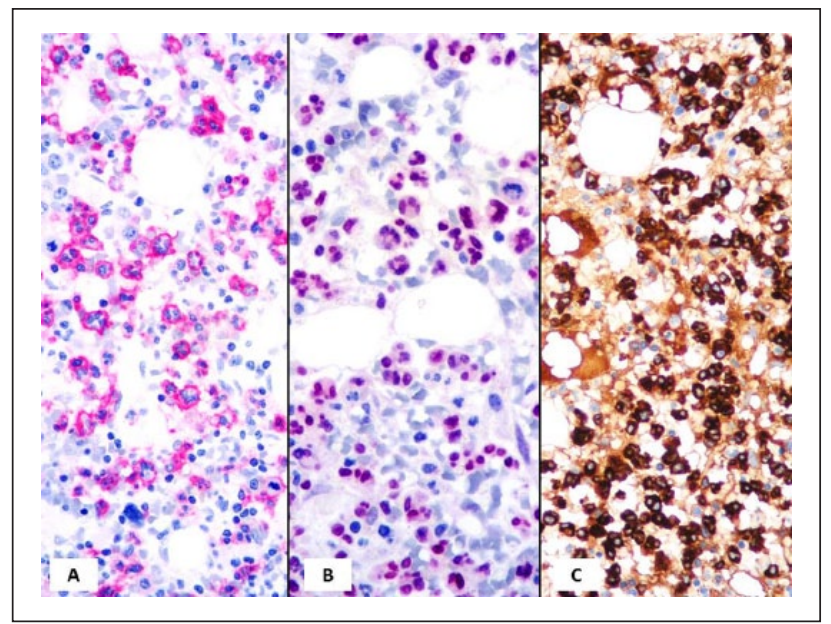

Figure 2. Positive staining with CDI38 (A), MUMI/IRF4 (B) and kappa chain $(C)$ of the neoplastic multilobated plasma cells.

considered at high cytogenetic risk. After radiotherapy on bone lesions (total dose $25 \mathrm{~Gy}$ ), the patient is currently on thalidomide, bortezomib, and dexametasone induction therapy for autologous stem cell transplantation.

Multiple myeloma with multilobated/multinucleated plasma cells is a very uncommon ( $2 \%$ to $8 \%)$ morphological variant often characterized by an aggressive clinical course. The unusual morphological features of large bizarre multilobated plasma cells can make its diagnosis difficult to achieve. Immunohistochemistry is essential in order to avoid misdiagnosis especially with myeloid/ monocytic leukemia or nonhematological malignancies.

\section{ORCID iD}

Maria Cecilia Mengoli (D) http://orcid.org/0000-0002-1437-8747

\footnotetext{
'Azienda Unità Sanitaria Locale/IRCCS, Reggio Emila, Italy

${ }^{2}$ Ospedale S. Giovanni di Dio, University of Cagliari, Cagliari, Italy

${ }^{3}$ Ospedale di Terni, University of Perugia, Perugia, Italy
}

\section{Corresponding Author:}

Maria Cecilia Mengoli, Pathology Unit, Azienda Unità Sanitaria Locale/ IRCCS, Viale Risorgimento 80, 42I23 Reggio Emilia, Italy.

Email: cecilia.mengoli@gmail.com 